JIAFE (Jurnal Ilmiah Akuntansi Fakultas Ekonomi)

https://journal.unpak.ac.id/index.php/jiafe
Vol. 7 No. 1, Juni 2021, Hal. 35-48

P-ISSN: 2502-3020, E-ISSN: 2502-4159

\title{
DETERMINASI INTEGRITAS LAPORAN KEUANGAN PERUSAHAAN GO PUBLIC DI BURSA EFEK INDONESIA
}

\author{
Intan Nurul Oktaviani ${ }^{1}$, Husnah Nur Laela Ermaya ${ }^{2}$, Dwi Jaya Kirana ${ }^{3}$ \\ 1,2,3 Universitas Pembangunan Nasional Veteran Jakarta, Jakarta, Indonesia \\ Email korespondensi: ${ }^{1}$ intan.nurul@upnvj.ac.id
}

\begin{abstract}
ABSTRAK
Penelitian ini bertujuan untuk mengetahui pengaruh komisaris independen, kepemilikan institusional, kepemilikan manajerial, kualitas audit, spesialisasi industri auditor, dan ukuran perusahaan terhadap integritas laporan keuangan. Populasi penelitian adalah seluruh perusahaan go public non keuangan yang tercatat di Bursa Efek Indonesia (BEI). Sampel penelitian berjumlah 400 perusahaan dengan metode purposive sampling. Pengujian hipotesis menggunakan analisis regresi linier berganda.Hasil dari penelitian menunjukkan komisaris independen, kepemilikan institusional, kualitas audit, spesialisasi industri auditor serta ukuran perusahaan mempengaruhi integritas laporan keuangan. Untuk kepemilikan manajerial tidak mempengaruhi integritas laporan keuangan. Implikasinya yaitu perseroan harus mengamati tingkat komisaris independen, kepemilikan institusional, kualitas audit, spesialisasi industri auditor serta ukuran perusahaan karena sangat mempengaruhi integritas laporan keuangan. Selaain itu, kepemilikan manajerial sebaiknya persentase saham yang dipunya manajemen ditingkatkan karena pihak manajerial sekaligus pemegang saham akan terus berusaha untuk bekerja dengan maksimal, dan berupaya meningkatkan kinerja dan nilai perusahaan.
\end{abstract}

Kata kunci: integritas laporan keuangan; kepemilikan manajerial; komisaris independen; kualitas audit; spesialisasi industri auditor

\begin{abstract}
This study aims to determine the effect of independent commissioners, institutional ownership, managerial ownership, audit quality, auditor industry specialization, and firm size on the integrity of financial statements. The research population is all non-financial go public companies listed on the Indonesia Stock Exchange (IDX). The research sample amounted to 400 companies with purposive sampling method. Hypothesis testing using multiple linear regression analysis. The results of the study show that independent commissioners, institutional ownership, audit quality, auditor industry specialization and company size affect the integrity of financial statements. For managerial ownership does not affect the integrity of financial statements. The implication is that the company must observe the level of independent commissioners, institutional ownership, audit quality, auditor industry specialization and company size because it greatly affects the integrity of financial statements. In addition, managerial ownership should increase the percentage of shares owned by management because the managerial parties as well as shareholders will continue to strive to work optimally, and strive to improve the performance and value of the company.
\end{abstract}

Keywords: auditor industry specialization; audit quality; independent commissioner; integrity of financial statements; managerial ownership

\section{KETERANGAN ARTIKEL}

Riwayat Artikel: diterima: 12 November 2020; direvisi: 30 Maret 2021; disetujui: 1 Juni 2021

Klasifikasi JEL: M40, M41

Cara mensitasi: Octaviani, N., I., Ermaya, H., N., L., \& Kirana, D., J. (2021). Determinasi Integritas Laporan Keuangan Perusahaan Go Public di Bursa Efek Indonesia. JIAFE (Jurnal IImiah Akuntansi Fakultas Ekonomi), 7(1), 35-48. https://doi.org/10.34204/jiafe.v7i1.2615 
Intan Nurul Octaviani: Determinasi Integritas Laporan ...

\section{PENDAHULUAN}

Setiap perusahaan menyampaikan informasi laporan keuangan untuk alat komunikasi dengan pihak manajemen dan penanam modal atapun stakeholder. Laporan keuangan harus memiliki informasi sesuai dengan kriteria relevan dan keandalan (reliabilitas). Statement of Financial Accounting Concept No. 2 mengatakan laopran keuangan harus menyajikan data yang jujur, benar, opini wajar serta menyajikan sesuai dengan kenyataan atau keadaan. Mewujudkan integritas laporan keuangan sangatlah sulit karena berbagai macam kasus salah saji (Indrasari dkk., 2016), di antaranya PT Garuda Indonesia Tbk (GIAA). Perusahaan mengakui piutang menjadi pendapatan yang didapat dari PT Mahata terkait penyediaan layanan konektivitas dalam penerbangan, sehingga laporan keuangan GIAA tercatat laba bersih sejumlah US\$809,85 padahal saat kuartal ketiga tahun 2018 perusahaan mencatat kerugian sebesar US\$114,08 juta (Pratiwi, 2019). Kasus lainnya yaitu PT Hanson Internasional Tbk (MYRX) terbukti melanggar akuntansi aktivitas real estate (PSAK 44) mengenai penjualan tanah atau kavling siap bangun, sehingga penghasilan PT Hanson tahun 2016 terlalu tinggi yaitu sebesar Rp613 miliar (Idris, 2020). Dari kedua kasus tersebut masih terdapat kecurangan saat penyajian laporan keuangan membuat integritas laporan keuangan lemah.

Keraguan pemakai laporan keuangan mengenai integritas laporaan keuangan membuat spekulasi terkait tata kelola perusahan menyebabkan tidak bisa meminimalisir kecurangan manajer saat menyajikan laporan keuangan. Komisaris independen, kepemlikan institusional, serta kepemilkian manjerial adalah bagian struktur yang memiliki kontribusi serta kedudukan yang baik guna melakukan pengawasan. Peraturan Otoritas Jasa Keuangan (OJK) No. 33/POJK.04/2014 menjelaskan komisaris independen sebagai aspek yang dapat di pandang apakah emiten atau perusahaan telah menerapkan good corporate governance. Komisaris independen bertanggung jawab kepada pemegang saham untuk melindunginya dari kasus kecurangan (Mais \& Nuari, 2016). Menurut penelitian terdahulu yakni penelitian Nurdiniah \& Pradika (2017) serta Irawati \& Fakhruddin (2016) mengungkapkan komisaris independen mempengaruhi positif atas integritas laporan keuangan. Sementara penelitian Mudasetia \& Solikhah (2017), serta Atiningsih \& Suparwati (2018) mengatakan komisaris independen tidak memengaruhi integritas laporan keuangan.

Terdapat struktur kepemilikan yang bertugas sebagai sistem pengendali untuk menurunkan konflik kepentingan yakni kepemilikan institusional. Dengan melaksanakan monitoring kepemilikan institusional bisa terhindar dari namanya salah saji dalam laporan keuangan yang dilakukan perusahaan untuk membuat investor berminat. Kaitannya integritas laporan keuangan dengan kepemilikan institusional yaitu kepemilikan institusional bisa membuat monitoring menjadi lebih ketat ke perusahaan agar manajer tidak melakukan praktik kecurangan dengan mengubah laba perusahaan agar membuat laporan keuangan tetap berintegritas dengan baik. Penelitian Sukanto \& Widaryanti (2018) mengatakan kepemilikan institusional memengaruhi positif atas integritas laporan keuangan. Penelitian Mudasetia \& Solikhah (2017) mengatakan "kepemilikan institusional tidak mempengaruhi integritas laporan keuangan".

Elemen lainnya dari struktur kepemilikan adalah kepemilikan manajerial. Kepemilikan manajerial berperan penting dalam mengambil keputusan mengenai bermacam kebijakan perusahaan yang didalamnyayaitu penyajian laporan keuangan. Integritas laporan keuangan bisa ditingkatkan melalui diterapkannya pengawasan oleh kepemilikan manajerial (Mudasetia \& Solikhah, 2017). Semakin tinggi tingkat kepemilikan manajerialbisa menaikkan kualitas keuntungan menjadikan profit atau laba memiliki 
JIAFE (Jurnal Ilmiah Akuntansi Fakultas Ekonomi)

https://journal.unpak.ac.id/index.php/jiafe
Vol. 7 No. 1, Juni 2021, Hal. 35-48

P-ISSN: 2502-3020, E-ISSN: 2502-4159

kekuatan responsif yang mampu membagikan respon positif untuk pemegang saham dan pelaku pasar modal. Menurut penelitian Arista dkk. (2018) dan Dewi \& Putra (2016) mengatakan "kepemilikan manajerial memengaruhi positif integritas laporan keuangan". Berbanding terbalik dengn penelitian Mudasetia \& Solikhah (2017) mengatakan "variabel kepemilikan manajerial tidak mempengaruhi integritas laporan keuangan".

Terdapat pihak luar yakni auditor untuk memantau manajer dalam menyajikan laporan keuangan. Auditing adalah penilaian serta pengumpulan bukti mengenai data informasi guna melaporkan dan menetapkan kesamaan data dengan ketentuan yang sudah dibuat. Kualitas jasa sangat diperlukan auditor untuk memberikan keyakinan bagi pengguna. Kantor Akuntans Publik (KAP) ternama memiliki dorongan motivasi untuk mengaudit lebih akurat dibandingan dengan KAP kecil (Suciani \& Suprantiningrum, 2018). Penelitian terdahulu yang dilaksanakan oleh Tussiana \& Lastanti (2016) mengatakan kualitas audit memengaruhi integritas laporan keuangan. Selain itu, penelitian Irawati \& Fakhruddin (2016) mengatakan kualitas audit memengaruhi signifikan negatif atas integritas laporan keuangan. KAP juga membuat spesialisasi industriagar bertujuan untuk menaikkan kemampuan auditor dalam memberikan kualitas yang lebih pada jasa audit, maka hasil auditnya akan lebih akurat. Penelitian Tussiana \& Lastanti (2016) mengatakan variable spesialisasi auditor tidak memengaruhi integritas laporan keuangan.

Kecil besarnya ukuran suatu perusahaan dinilai dapat memberikan pengaruh kepada manajer saat memplubikasikan laporan keuangan yang mempunyaiintegritas. Penelitian Nurdiniah \& Pradika (2017) mengungkapkan ukuran perusahaan memengaruhi integritas laporan keuangan. Biasanya ukuran perseroan yang besar akan menyajikan informasi dengan jujur atau sesuai fakta, sehingga mengambarkan laporan keuangan mempunyai integritas tinggi sehingga menciptakan akuntabilitas publik. Berdasarkan penjelasan yang sudah dibahas, penelitian ini meneliti tentang determinasi integritas laporan keuangan perusahaan go public di BEI dengan menggunakan variabelkomisaris independen, kepemilikan institusional, kepemilikan manajerial, kualitas audit, spesialisasi industri auditor serta ukuran perusahan sebagai variabel kontrol.

Tujuan penelitian yakni untuk memperoleh bukti yang empiris mengenai pengaruh komsaris independen, kepemilikan institusional, kepemilikan manajerial, kualitas audit, spesialisasi industri auditor dan ukuran perusahan terhadap integritas laporan keuangan. Karena hasil penelitian sebelumnya terkait faktor-faktor memengaruhi integritas laporan keuangan masih belum konsisten atau masih belum mempunyai hasil yang sama.

\section{KAJIAN LITERATUR DAN PENGEMBANGAN HIPOTESIS}

\section{Teori Agensi (Agency Theory)}

Keagenan yakni suatu kerjasama di mana terdapat satu atau lebih pemegang saham (principal) memberikan tugaskepada manajemen (agent) untk melaksanakan sebuah jasa dengan nama pemegang saham dan memberikan kekuasaan terhadap agent guna mengambil keputusan yang tepat untuk pemegang saham" (Jensen \& Meckling, 1976). Oleh karena itu, sebagian kekuasaan diberikan oleh manajeman (agent) untuk mengambil keputusan guna kepentingan principal dan manajemen wajib bertanggung jawab atas keputusan yang dibuatnya. Terdapat dua hubungan keagenan antara lain hubungan manajemen dengan pemegang sahan seta hubungan manajemen dengan pemberi pinjaman. Di dalam teori keagenan terdapat masalah yang timbul, karena sulit bagi pemegang saham untuk menyakini manajemen (agent) akan berlaku sesuai dengan kepentingannya maka timbullah konflik kepentingan atau konflik keagenan. Konflik keagenan bisa mempersulit serta memperlambat peseroan dalam menggapai kinerja positif untuk menciptakan nilai bagi perseroan serta untuk stakeholders. 
Intan Nurul Octaviani: Determinasi Integritas Laporan ...

\section{Integritas Laporan Keuangan}

Laporan keuangan yang berintegritas tinggi telah melengkapi dua spesifikasi utama, yaitu relevance dan keandalan dalam laporan keuangan. Informasi penyajian laporan keuangan dengan integritas tinggi mempunyai keahlian dalam membantu pembuatan keputusan untuk pemakai laporan keuangan. Menurut Istiantoro dkk. (2017) pengungkapan serta penyajian laporan keuangan didalamnya terdapat informasi akuntansi dengan menjelaskan aktualitas ekonomi perseroan yang sesungguhnya dan dijelaskan dengan jujur tanpa ditutupi merupakan definisi integritas laporan keuangan.

\section{Komisaris Independen}

Komisaris independen yaitu dewan komisaris independen yang bersumber dari eksternal perseroan (Sukanto \& Widaryanti, 2018). Berfungsi untuk menilai dan memantau hasil kinerja perusahaan secara menyeluruh serta mempunyai tujuan menyelaraskan dalam pembuatan keputusan terutama dalam melindungi pihak minoritas pemegang saham dan juga sebagai penengah apabila terdapat perbedaan pendapat antar manajemen dalam perusahaan (Hardiningsih, 2010). Komisaris independen bisa mengatasi masalah agensi yang mungkin terjadi dengan melakukan pengawasan sehingga good corporate governance dapat diterapkan dan menyajikan laporan keuangan berintegritas. Karena adanya sistem yang melakukan monitoring serta perlindungan hak-hak eksternal perusahaan. Jadi semakin tinggi komisaris independen menyebabkan laporan keuangan berintegritas. Namun jika semakin besar komisaris independen yang mempunyai kemampuan serta pengalaman yang bermacam-macam, mungkin dapat menurunkan kemampuan dewan komisaris independen saat melaksanakan monitoring karena timbul masalah koordinasi, komunikasi dan pembuatan keputusan. Savero (2017) dan Yulinda (2016) mengungkapkan komisaris independen memengaruhi integritas laporan keuangan. Peneliti merumuskan hipotesis sebagai berikut.

\section{$\mathrm{H}_{1}$ : komisaris independen berpengaruh terhadap integritas laporan keuangan}

\section{Kepemilikan Institusional}

Kepemilikan institusional yaitu persentase kepemilikan saham yang dipunya institusi lain baik institusi luar ataupun dalam negeri (Sukanto \& Widaryanti, 2018). Proses penyusunan laporan keuangan dapat dipengaruhi oleh saham institusi dan memungkinkan adanya akrualisasi sesuai kepentingan pihak manajemen. Konflik keagenan yang timbul dari teori agensi dapat dikatakan bahwa monitoring yang dilaksanakan oleh kepemilikan institusional bisa membuat manajemen memusatkan perhatiannya terhadap kinerja perusahaan sehingga dapat meminimalisir tindakan opportunistic (Suciani \& Suprantiningrum, 2018). Dan dapat mengantisipasi salah saji pada laporan keuangan yang bisa saja dilakukan sehingga penyajian laporan keuangan berintegritas. Pernyataan tersebut sejalan dengan penelitian penelitian Sukanto \& Widaryanti (2018), Dewi \& Putra (2016) serta Atiningsih \& Suparwati (2018) mengungkapkan "kepemilikan institusional memengaruhi positif atas integritas laporan keuangan".

\section{H2: kepemilikan institusional berpengaruh terhadap integritas laporan keuangan}

\section{Kepemilikan Manajerial}

Kepemilikan manajerial didefinisikan presentase saham yang dipunya manajer serta direksi suatu entitas yang berperan langsung saat pembuatan keputusan perusahaan (Atiningsih \& Suparwati, 2018). Kepemilikan manjerial sendiri merupakan mekanisme yang bisa berfungsi untuk menaikkan integritas laporan keuangan. Masalah keagenan dapat timbul apabila persentase kepemilikan saham manajer perseroan $<100 \%$ sehingga manajer berperilaku oppurtinistic dan saat mengambil keputusan tidak 
JIAFE (Jurnal Ilmiah Akuntansi Fakultas Ekonomi)

https://journal.unpak.ac.id/index.php/jiafe
Vol. 7 No. 1, Juni 2021, Hal. 35-48

P-ISSN: 2502-3020, E-ISSN: 2502-4159

bersadarkan pada memaksimalkan nilai perusahaan. Konflik keagenan tersebut dapat di atasi dengan adanya pengawasan. Akan tetapi, dengan timbulnya mekanisme monitoring akan timbul agency cost. Untuk mengurangi biaya agensi yaitu dengan meningkatkan saham kepemilikan manajerial sehingga manajer mendapatkan manfaat langsung dari pengambila keputusan. Semakin tinggi persentase saham manajer akan mempunyai tanggung jawab serta posisi yang kuat saat mengelola perseroan, mengambil keputusan serta penyajian laporan keuangan sebagai informasi yang jujur serta betul agar mempunyai integritas laporan keuangan yang tinggi. Searah dengan penelitian Arista dkk. (2018), Atiningsih \& Suparwati (2018), serta Dewi \& Putra (2016) mengungkapkan kepemilikan manajerial memengaruhi positif integritaslaporan keuangan. Peneliti merumuskan hipotesis sebagai berikut.

H3: kepemilikan manajerial berpengaruh terhadap integritas laporan keuangan

\section{Kualitas Audit}

Kuallitas audit didefinisikan sebagai sejauh mana auditor bisa menemukan dan memberitahukan temuannya secara baik atau tidak jika terdapat sebuah kesalahan atau kecurangan yang ada pada penyajian informasi akuntasi atau laporan keuangan kliennya (Mudasetia \& Solikhah, 2017). Kaitannya kualitas aduit dengan teori keagenan di mana terdapat ketidakseimbangan penguasaam informasi antar agent dan principal hal ini menimbulkan asimetri informasi (information asymmetry). Maka diperlukan pihak ketiga yang independen yakni akuntan publik atau auditor (Puspita \& Utama, 2016). KAP big four terkesan lebih independen dalam mengaudit dibandikan KAP non big four. KAP big four juga diyakini dalam mengaudit akan hati-hati dan teliti sehingga kualitas yang dihasilkan bagus akan membuat laporan keuangan berintegritas. Pernyataan tersebut di dukung oleh penelitian Tussiana \& Lastanti (2016), Puspita \& Utama (2016), serta Mudasetia \& Solikhah (2017) mengungkapkan kualitas audit memengaruhi integritas laporan keuangan. Peneliti merumuskan hipotesis sebagai berikut.

\section{$\mathrm{H}_{4}$ : kualitas audit berpengaruh terhadap integritas laporan keuangan}

\section{Spesialisasi Industri Auditor}

Spesialisasi industri auditor didefinisikan sebagai pengalaman serta kemampuan auditor dalam mengaudit pada bidang industri tertentu (Qonitin \& Yudowati, 2018). Dukungan pasar modal dan kepercayaan investor dapat ditingkatkan dengan menggunakan jasa industri auditor spesialis. Keberadaan spesialisasi industri memiliki tujuan yaitu menaikkan kompetensi dalam menyediakan jasa audit berkualitas tinggi agar audit yang dihasilkan lebih akurat. Spesialisasi industri auditor juga mempunyai pengetahuan lebih terkait perusahaan yang diauditnya dan dapat mengidentifikasi risiko khusus yang ada pada industri tersebut agar mempermudah auditor saat mendapatkan kesalahan material baik yang muncul karena pelanggaran ataupun kesalahan. Penelitian Sipahutar (2017) dan Syura (2018) mengungkapkan spesialisasi industri auditor memengaruhi integritas laporan keuangan. Disebabkan spesialisasi industri auditor terpusat pada satu industri saja sehingga kualitas yang dihasilkan juga akan bagus. Dari penjelasan di atas, maka peneliti merumuskan hipotesis sebagai berikut.

H5: spesialisasi industri auditor berpengaruh terhadap integritas laporan keuangan

\section{METODE PENELITIAN}

Metode penelitian yang digunakan yaitu kuantitatif dengan jenis penelitiannya yaitu statistik deskriptif. Populasi penelitian ini adalah perusahaan go public non keuangan sebanyak 591 perusahaan. Sampel penelitian dipilihi menggunakan metode purposive sampling dengan kriteria: (1) perusahaan go public non keuangan yang tidak delisting di Bursa Efek Indonesia pada periode 2016-2018; (2) perusahaan go 
Intan Nurul Octaviani: Determinasi Integritas Laporan ...

public non keuangan yang mengunggah laporan tahunan di website Bursa Efek Indonesia tahun 20162018 (www.idx.co.id); (3) perusahaan yang memiliki informasi berhubungan dengan variabel-variabel yang digunakan pada penelitian. Dengan demikian, dipilih 400 perusahan yang dijadikan sampel. Jenis data pada penelitian ini adalah data sekunder yang dikumpulkan dari situs web resmi BEI dan situs web resmi perseroan. Metode pengujian hipotesis menggunakan analisis linier berganda. Berikut bentuk persamaan uji regresi pada penelitian ini, yaitu.

$$
Y=\alpha+\beta_{1} X_{1}+\beta_{2} X_{2}+\beta_{3} X_{3}+\beta_{4} X_{4}+\beta_{5} X_{5}+\beta_{6} X_{6}+\varepsilon
$$

Variabel terikat pada penelitian ini yaitu integritas laporan keuangan yang diproksikan menggunakan prinsip konservatisme. Prinsip konservatisme digunakan sebagai proksi integritas laporan keuangan karena prinsip konservatisme mendorong laporan keuangan disajikan dengan sangat berhatihati (understate) dengan risiko sedikit, dibandingkan yang disajikan dengan penyajian laporan keuangan yang terlalu optimis (overstate) (Arista, dkk., 2018). Berikut formula yang digunakan untuk mengukur tingkat konservatisme.

$$
\text { CONNACC }=(\text { Niit }- \text { CFOit })
$$

Keterangan dari persamaan tersebut sebagai berikut: (1) CONNACC adalah tingkat konservatisme; (2) Niit adalah laba bersih ditambah depresiasi dan amortisasi; (3) CFOit adalah arus kas kegiatan operasional.

Variabel independen pada penelitian ini diukur menggunakan proksi sebagai berikut. Komisaris independen yaitu dewan komisaris independen yang bersumber dari eksternal entitas. Berikut formula yang digunakan untuk mengukur komisaris independen.

$$
K I=\frac{\text { Jumlah } \text { komisaris independen }}{\text { Jumlah dewan komisaris }}
$$

Kepemilikan institusional diukur menggunakan presentase kepemilikan saham dipunya perusahaan lain baik perusahaan luar ataupun dalam negeri merupakan definisi dari (Sukanto \& Widaryanti, 2018). Berikut formula yang digunakan untuk mengukur kepemilikan institusional.

$$
I N S T=\frac{\text { Jumlah saham yang dimiliki institusi }}{\text { Jumlah saham yang beredar }}
$$

Kepemilikan manajerial diukur menggunakan presentase saham yang dimiliki oleh dewan komisaris serta direksi suatu perusahaan secara langsung terlibat dalam pembuatan keputusan (Atiningsih \& Suparwati, 2018). Berikut formula yang digunakan untuk mengukur kepemilikan manajerial.

$$
M N J M=\frac{\text { Jumlah saham yang dimiliki manajemen }}{\text { Jumlah saham yang beredar }}
$$

Kualitas audit didefinisikan sebagai sebuah peluang di mana auditor bisa mendeteksi serta meberitahukan penemuannya secara baik atau tidak jika terdapat suatu kesalahan atau kecurangan yang ada pada penyajian informasi akuntasi atau laporan keuangan kliennya (Mudasetia \& Solikhah, 2017). Penelitian ini menggunakan variabel dummy, yaitu jika perusahaan yang diaudit oleh KAP yang terafiliasi big four diberi angka 1 dan jika auditor yang mengaudit KAP non big four diberi angka 0. 
JIAFE (Jurnal Ilmiah Akuntansi Fakultas Ekonomi)

https://journal.unpak.ac.id/index.php/jiafe
Vol. 7 No. 1, Juni 2021, Hal. 35-48

P-ISSN: 2502-3020, E-ISSN: 2502-4159

Spesialisasi industri auditor diproksikan dengan pengalaman dan keahlian auditor dalam mengaudit pada sektor industri tertentu (Qonitin \& Yudowati, 2018). Industri auditor spesialis diukur menggunakan pengukuran yang digunakan oleh Fajaryani (2015).

$$
I N D S T R=\frac{\text { Perusahaan yang diaudit oleh KAP dalam satu industri }}{\text { Perusahaan di dalam industri }}
$$

Ukuran perusahaan diukur menggunakan logaritma natural aset perusahaan. Berikut formula yang digunakan untuk mengukur ukuran perusahaan.

\section{HASIL DAN PEMBAHASAN}

$$
\text { Ukuran perusahaan }=\operatorname{Ln}(\text { total aset })
$$

Berikut disajikan tabel hasil pengujian statistik deskriptif untuk menggambarkan kondisi variabel penelitian.

Tabel 1. Hasil Uji Statistik Deskriptif

\begin{tabular}{llrrrr}
\hline & N & Minimum & Maksimum & Mean & \multicolumn{1}{c}{ Std. Deviation } \\
\hline Integritas & 400 & -264.839 .011 .400 & 613.436 .000 .000 & 63.354 .142 .239 & 133.050 .283 .000 \\
Kom. & 400 & 0,200 & 0,800 & 0,396 & 0,089 \\
Independen & & 0,051 & 0,999 & 0,734 & 0,205 \\
Kep. Institusi & 400 & 0,000 & 0,873 & 0,073 & 0,138 \\
Kep. Manajer & 400 & 0,007 & 0,239 & 0,079 & 0,059 \\
$\begin{array}{l}\text { Spes. Industri } \\
\text { Auditor }\end{array}$ & 400 & 24,568 & 32,039 & 27,986 & 1,332 \\
$\begin{array}{l}\text { Ukuran } \\
\text { Valid N (List- }\end{array}$ & 400 & & & & \\
wise) & 400 & & & & \\
\hline
\end{tabular}

Berdasarkan Tabel 1, nilai terendah integritas laporan keuangan sebesar Rp264.839.011.400dan nilai maksimumnya yaitu sebesar Rp613.436.000.000. Untuk nilai mean pada integritas laporan keuangan sebesar Rp63.354.142.239. Nilai tersebut menunjukan bahwa perusahaan go public nonkeuangan yang dijadikan sampel dalam penelitian membuktikan net income lebih besar dibanding cash flow operasi membuat rata-rata prinsip konservatisme tidak dipraktikan saat penyajian laporan keuangan. Karena dalam prinsip konservatisme seharusnya arus kas operasi lebih besar dari pada net income yang mengindikasikan diterapkannya prinsip konservatisme. Standar deviasi atau simpangan baku dari integritas laporan keuangan yaitu sebesar Rp133.050.282.009.

Nilai terendah komisaris independen sebesar $20 \%$, serta nilai tertinggi sebesar $80 \%$. Sedangkan nilai mean komisaris independen pada setiap perusahaan yakni sebesar $39,63 \%$ yang menunjukkan bahwa setiap perusahaan go public non keuangan telah menerapkan sesuai peraturan OJK No. 33/POJK.04/2014 mengenai dewan direksi serta dewan komisaris wajib mempunyai komisaris independen minimal sebesar $30 \%$. Sementara untuk melihat simpangan baku dari komisaris independen bisa dilihat dari nilai standar deviasinya yakni sebesar $8,88 \%$.

Nilai terendah kepemilikan institusional sebanyak 5,14\% serta nilai maksimum sebesar $99,88 \%$, sedangkan nilai mean sebesar $73,42 \%$ yang menunjukan bahwa mean kepemilikan saham perusahaan oleh pihak institusi sebesar $73,42 \%$ dari total saham beredar. Artinya kepemilikan saham yang dipunya 
Intan Nurul Octaviani: Determinasi Integritas Laporan ...

oleh perusahaan banyak dipunyai oleh institusi, yakni seperti reksadana, bank, dana pensiun, perusahaan asuransi serta institusi lainnya.

Nilai terendah kepemilikan manajerial yaitu sejumlah $0,00 \%$ serta nilai tertinggi sejumlah $87,33 \%$. Untuk nilai mean sejumlah $7,29 \%$. Artinya saham yang dimiliki manajer dalam perusahaan masih sangatlah kecil. Hasil uji statistik deskriptif untuk kualitas audit nilai minimumnya yaitu 0 sebanyak 290 perusahaan dan nilai maksmimumnya yaitu 1 sebanyak 110 perusahaan. Artinya, kualitas audit pada data sampel dalam penelitian banyak menggunakan jasa yang dihasilkan oleh KAP non-big four dalam mengaudit laporan keuangan. Untuk nilai rata-rata sejumlah 0,27 serta simpang baku sejumlah 0,447.

Berdasarkan uji statistik deskriptif menggambarkan bahwa variabel spesialisasi industri auditor nilai terendah sejumlah $0,69 \%$ serta nilai tertinggi sejumlah $23,88 \%$. Nilai rata-rata sejumlah $7,94 \%$, ini menerangkan perusahaan yang memakai jasa spesialisasi industri auditor masih sangatlah kecil dan standar deviasi sebesar 5,96\%. Variabel kontrol yakni ukuran perusahaan, nilai minimumnya yaitu sebesar 24,56831 atau sebesar Rp46.760.927.085 dan nilai maksimum ukuran perusahaan sebesar 32,03987 atau Rp82.174.515.000.000. Sedangkan untuk nilai mean sebesar 27,986 artinya sampel perusahaan di penelitian ini tergolong perusahaan besar dan untuk standar deviasi sebesar 1,332.

Hasil pengujian koefisien determinasi menunjukkan nilai Adjusted $R$ Square sebesar 0,369 atau 36,9\%. Dengan demikian, variabel komisaris independen, kualitas audit, kepemilikan institusional, spesialisasi industri auditor, kepemilikan manajerial dan ukuran perusahaan sebagai variabel kontrol sejumlah $36,9 \%$ dari $100 \%$ bisa menjelaskan faktor memengaruhi integritas laporan keuangan. Untuk sisanya sebesar $63,1 \%$ dipengaruhi oleh variabel lain.

Tabel 5. Hasil Uji Koefisien Determinasi

\begin{tabular}{llllllr}
\hline Model & $\mathrm{R}$ & $\mathrm{R}$ Square & $\begin{array}{l}\text { Adjusted } \\
\text { Square }\end{array}$ & $\begin{array}{l}\text { Std. Error of the } \\
\text { Estimate }\end{array}$ & 105652995999 & \\
\hline 1 & $0,616^{\mathrm{a}}$ & 0,379 & 0,369 & & 105659 \\
\hline
\end{tabular}

Tabel 6 berikut menunjukkan hasil uji parsial (uji t) sebagai analisis hipotesis penelitian.

Tabel 6. Hasil Uji Parsial (Uji t)

\begin{tabular}{llrrr}
\hline \multicolumn{1}{c}{ Model } & $\begin{array}{c}\text { Standardize } \\
\boldsymbol{d} \\
\end{array}$ & $\begin{array}{c}\text { Coefficients } \\
\text { Beta }\end{array}$ & t & Sig. \\
\hline 1 (Constant) & & $-11,136$ & 0,000 \\
& Kom. Independen & $-0,137$ & $-3,397$ & 0,001 \\
Kep. Institusi & 0,302 & 5,744 & 0,000 \\
Kep. Manajer & 0,015 & 0,291 & 0,771 \\
Kualitas Audit & 0,150 & 2,816 & 0,005 \\
Spes. Industri Auditor & $-0,174$ & $-3,274$ & 0,001 \\
Ukuran & 0,490 & 11,33 & 0,000 \\
& & & \\
\hline
\end{tabular}

Berdasarkan tabel variabel komisaris independen menunjukkan nilai signifikan $<0,05(0,001<0,05)$ sehingga $\mathrm{H}_{1}(\mathrm{Ha})$ diterima. Untuk t hitung memiliki nilai negatif sebesar $-3,397$. Dengan ini, komisaris independen mempengaruhi signifikan negatif atas integritas laporan keuangan. Variabel kepemilikan institusional memperlihatkan nilai signifikan $<0,05(0,000<0,05)$ sehingga $\mathrm{H}_{2}(\mathrm{Ha})$ diterima. Kemudian, $\mathrm{t}$ 
JIAFE (Jurnal Ilmiah Akuntansi Fakultas Ekonomi)

https://journal.unpak.ac.id/index.php/jiafe
Vol. 7 No. 1, Juni 2021, Hal. 35-48

P-ISSN: 2502-3020, E-ISSN: 2502-4159

hitung memiliki nilai positif sebesar 5,744. Dengan ini, kepemilikan institusional mempengaruhi signifikan positif atas intergitas laporan keuangan.

Variabel kepemilikan manajerial memperlihatkan nilai signifikan $>0,05(0,771>0,05)$ maka $\mathrm{H}_{3}(\mathrm{Ha})$ ditolak. $t$ hitung memiliki nilai positif sebesar 0,291. Dengan ini, kepemilikan manajerial tidak memengaruhi intergitas laporan keuangan. Variabel kualitas audit memperlihatkan nilai signifikan $<0,05$ $(0,005<0,05)$ maka $\mathrm{H}_{4}(\mathrm{Ha})$ diterima. T hitung memiliki nilai positif sebesar 2,816 . Dengan ini kualitas audit mempengaruhi signifikan positif atas intergitas laporan keuangan. Variabel spesialisasi industri auditor memperlihatkan nilai signifikan $<0,05(0,001<0,05)$ sehingga $\mathrm{H}_{5}(\mathrm{Ha})$ diterima. T hitung memiliki nilai negatif sebesar $-3,274$. Dengan ini, spesialisasi industri auditor mempengaruhi signifikan negatif atas integritas laporan keuangan. Variabel kontrol ukuran perusahaan memperlihatkan nilai signifikan $<0,05$ $(0,000<0,05)$ maka $\mathrm{H}_{6}(\mathrm{Ha})$ diterima. T hitung memiliki nilai positif sebesar 11,33 . Dengan ini, ukuran perusahaan mempengaruhi signifikan positif atas intergitas laporan keuangan.

Tabel 7. Hasil Uji Regresi Linier Berganda

\begin{tabular}{llcr}
\hline & \multicolumn{1}{c}{ Model } & \multicolumn{2}{c}{ Unstandardized } \\
& & Coefficients \\
& & $-27,931$ & Std. Error \\
\hline 1 & (Constant) & $-26,045$ & 25,520 \\
& Kom. Independen & 25,999 & 24,251 \\
& Kep. Institusi & 23,391 & 24,626 \\
& Kep. Manajer & 24,518 & 23,484 \\
& Kualitas Audit & $-26,687$ & 25,501 \\
& Spes. Industri Auditor & 24,613 & 22,186 \\
\hline
\end{tabular}

Didasarkan tabel 7, di atas yang sudah ditransformasi kedalam bentuk logaritma natural, maka model regresi yang terbentuk yakni sebagai berikut.

$$
\begin{aligned}
Y=-27,931-26,045 K I+ & 25,999 I N S T+23,391 M N J M+24,518 K A-26,687 I N D S T R+ \\
& 24,613 S I Z E+e
\end{aligned}
$$

\section{Pengaruh Komisaris Independen terhadap Integritas Laporan Keuangan}

Uji hipotesis yang sudah dilaksanakan pada variabel komisaris independen, memperlihatkan komisaris independen mempengaruhi signifikan negatif terhadapa integritas laporan keuangan, sehingga $\mathrm{H}_{1}$ diterima. Bisa dilihat komisaris independen memiliki nilai koefisien ke arah negatif, yang di mana jika presentase komisaris independen meningkat membuat integritas laporan keuangan akan menurun.

Konflik keagenan dapat diminimalisir dengan melakukan mekanisme pengawasan sehingga menciptakan good corporate governance (Jensen \& Meckling, 1976). Komisaris independen berperan mengawasi hasil kerja yang dilaksanakan oleh manajemen perusahaan. Landasan teori tersebut tidak sama dengan hasil uji regresi yang bernilai negatif karena besarnya jumlah komisaris independen tidak bisa menyeimbangkan kepentingan agent dengan principal, menyebabkan tidak tercapainya target perusahaan yakni dengan penyajian laporan keuangan berintegritas. Hal tersebut mungkin disebabkan 
Intan Nurul Octaviani: Determinasi Integritas Laporan ...

oleh semakin banyak komisaris independen yang mempunyai kemampuan serta pengalaman yang bermacam-macam, mengakibatkan menurunnya monitoring karena timbul masalah koordinasi, komunikasi serta pengambilan keputusan.

Selanjutnya ketidakefektifan ini karena pembentukan komisaris independen hanya melaksanakan peraturan Otoritas Jasa Keuangan yang sudah ditentukan tanpa disertai peningkatan kinerja yang baik yakni dengan menerapkan good corporate governance. Yang di mana peraturan OJK No. 33/POJK.04/2014 mengenai dewan direksi serta dewan komisaris wajib mempunyai komisaris independen minimal sebesar $30 \%$. Rata-rata komisaris independen pada penelitian 39,63\% yang di mana sampel dalam penelitian sudah memenuhi syarat peraturan yang berlaku. Namun belum mampu memberikan dampak yang baik khususnya dalam tugasnya melakukan monitoring terhadap manajer. Savero (2017) serta Yulinda (2016) mengungkapkan komisaris independen memengaruhi integritas laporan keuangan.

\section{Pengaruh Kepemilikan Institusional terhadap Integritas Laporan Keuangan}

Uji hipotesis kedua yang sudah dilaksanakan pada variabel kepemilikan institusional, memberikan hasil yakni kepemilikan institusional mempengaruhi signifikan positif atas integritas laporan keuangan, sehingga $\mathrm{H}_{2}$ diterima. Dari hasil regresi memperlihatkan koefisien ke arah positif, yang di mana jika presentasi kepemilikan institusional naik, maka laporan keuangan disajikan berintegritas.

Adanya investor institusional seperti bank, perusahaan investasi, asuransi, reksadana, dana pensiun serta institusi lainnya bisa mengurangi perilaku manajer yang mementingkan diri sendiri dan dapat melakukan pengawasan secara efektif. Hal ini sejalan dengan agency theory yang di mana monitoring yang diterapkan oleh kepemilikan institusional bisa membuat manajer untuk memusatkan perhatiannya kepada proses kerja perusahaan agar bisa meminimalisir perilaku opportunistic. Keberadaan saham institusi diperusahaan bisa meningkatkan pengawasan terhadap perilaku manajer saat mencegah salah saji pada laporan keuangan yang bisa saja dilaksanakan maka bisa menaikkan integritas laporan keuangan. Sesuai penelitian Sukanto \& Widaryanti (2018), Dewi \& Putra (2016) serta Atiningsih \& Suparwati (2018) mengungkapkan kepemilikan institusional memengaruhi integritas laporan keuangan.

\section{Pengaruh Kepemilikan Manajerial terhadap Integritas Laporan Keuangan}

Variabel kepemilikan manajerial memperlihatkan hasil kepemilikan manajerial tidak memengaruhi integritas laporan keuangan, sehingga $\mathrm{H}_{3}$ ditolak. Untuk mengurangi biaya agensi yaitu dengan meningkatkan saham kepemilikan manajerial sehingga manajer mendapatkan manfaat langsung dari pengambila keputusan. Selain itu juga dapat meminimalisir masalah konflik kepentingan antara pihak manajemen dengan pihak principal dengan cara meyelaraskan kepentingan keduanya. Tetapi hal tersebut tidak sejalan dengan uji hipotesis yang di mana peningkatan atau penurunan saham manajerial tidak dapat meminimalisir masalah keagenan yang timbul dari hubungan manajer dan principal sehingga perusahaan tidak bisa memenuhi nilai perusahaan dengan menyajikan informasi laporan keuangan yang mempunyai integritas.

Hasil olah data tidak sesuai dengan penelitian Arista dkk. (2018), Atiningsih \& Suparwati (2018), serta Dewi \& Putra (2016) mengungkapkan kepemilikan manajerial mempengaruhi positif integirtas laporan keuangan. Ketidaksamaan hasil penelitian dengan hipotesis mungkin karena persentase saham manajer terlalu kecil yaitu nilai rata-rata $7,29 \%$ yang berarti kepemilikan manajerial yang dipunyai oleh direksi dan dewan komisaris pada sampel penelitian masih sedikit sehingga manajer kurang berperan dalam pengambilan keputusan. Perusahaan terbuka yang di kelola biasanya memiliki saham manajerial. Namun, saham tersebut mungkin tidak bisa untuk berkontribusi dalam pembuatan keputusan membuat pihak manajer tidak dapat keuntungan yang diinginkan selaku bagian dari pemegang perseroan serta manajer tidak bisa menaikkan kinerjanya seperti yang diinginkan menyebabkan tidak mampu 
JIAFE (Jurnal Ilmiah Akuntansi Fakultas Ekonomi)

https://journal.unpak.ac.id/index.php/jiafe
Vol. 7 No. 1, Juni 2021, Hal. 35-48

P-ISSN: 2502-3020, E-ISSN: 2502-4159

mempengaruhi integritas laporan keuangan. Dari pengolahan data yang sudah dikerjakan di dukung oleh penelitian Mudasetia \& Solikhah (2017) dan Istiantoro dkk. (2017) mengatakan kepemilikan manajerial tidak memengaruhi integritas laporan keuangan.

\section{Pengaruh Kualitas Audit terhadap Integritas Laporan Keuangan}

Didasarkan hipotesis yang sudah dilaksanakan pada variabel kualitas audit, menjelaskan hasil kualitas audit mempengaruhi signifikan positif atas integritas laporan keuangan, berarti Hipotesis empat $\left(\mathrm{H}_{4}\right)$ diterima. Hasil uji pada t-hitung kualitas audit memiliki nilai koefisien ke arah positif, artinya jika kualitas audit bagus membuat laporan keuangan semakin berintegritas.

Dengan adanya ketidakseimbangan penguasaan informasi antara manajemen dan principal, maka dibutuhkan pihak ketiga yang independen yakni akuntan publik atau auditor. Hasil kualitas audit yang dikerjakan KAP big four diyakini saat mengerjakan audit lebih berhati-hati serta teliti membuat kualitas yang dihasilkan bagus. Karena KAP big four mempunyai inisiatif yang baik untuk menjauhi hal-hal yang bisa mencoreng reputasi KAP, dan jika terjadi maka akan merugikan KAP yakni dapat kehilangan klien. Sehingga audit yang disajikan auditor semakin berkualitas, membuat integritas laporan keuangan semakin bagus. Penelitian ini memperlihatkan bahwa 110 perusahaan yang menggunakan KAP big four. Yang di mana kualitas audit yang dikerjakan KAP big four mampu menaikkan integritas laporan keuangan dan mendapatkan opini wajar.Penelitian yang sesuai dengan hasil uji yaitu penelitian Tussiana \& Lastanti (2016), Puspita \& Utama (2016) serta Mudasetia \& Solikhah (2017) mengungkapkan kualitas audit memengaruhi integritas laporan keuangan.

\section{Pengaruh Spesialisais Industri Auditor terhadap Integritas Laporan Keuangan}

Didasarkan hipotesis yang sudah dilaksanakan pada variabel spesialisasi industri auditor, memperlihatkanhasil spesialisasi industri auditor mempengaruhi signifikan negatif atas integritas laporan keuangan, sehingga $\mathrm{H}_{5}$ diterima. Dapat dilihat spesialisasi industri auditor memiliki nilai koefisien ke arah negatif, yang di mana jika presentase spesialisasi industri auditor tinggi sehingga laporan keuangan menjadi tidak berintegritas.

Auditor yang mengurus klien pada industri tertentu akan mendapatkan pengetahuan yang lebih bagus, dari pada auditor yang mempunyai beberapa klien dalam industri sejenis. Pengetahuan lebih terkait industri klien beserta lingkungan yang diauditnya membuat auditor dapat mengidentifikasi risiko khusus yang ada pada industri tersebut agar mempermudah auditor saat mendapatkan kesalahan material baik yang muncul karena pelanggaran ataupun kesalahan pada laporan keuangan. Sehingga laporan keuangan dihasilkan auditor spesialisasi mempunyai integritas lebih bagus.

Namun hal tersebut terjadi jika presentasi spesialisasi industri auditor memiliki presentasi yang kecil. Sedangkan apabila spesialisasi industri auditor memiliki presentasi yang tinggi maka justru cenderung akan menurunkan integritas laporan keuangan yang diberikan. Hal ini mungkin disebabkan dari data sampel penelitian perusahaan yang menggunakan jasa spesialisai industri auditor masih sangatlah kecil. Selain itu, mungkin diduga jika perusahaan banyak menggunakan spesialisasi industri auditor membuat auditor lebih memahami industri tertentu, dan membuat auditor dapat bertindak melakukan kecurangan saat mengaudit dengan tidak melaporkan temuan atas pelanggaran tersebut.Penelitian yang sesuai dengan hasil uji yaitu penelitian sejalan dengan penelitian Sipahutar (2017) dan Syura (2018) menyatakan bahwa spesialisasi auditor memengaruhi integritas laporan keuangan. 
Intan Nurul Octaviani: Determinasi Integritas Laporan ...

\section{Pengaruh Ukuran Perusahaan terhadap Integritas Laporan Keuangan}

Didasarkan hipotesis yang sudah dilaksanakan pada variable kontrol pada variabel ukuran perusahaan, memberikan hasil yakni ukuran perusahaan mempengaruhi signifikan positif atas integritas laporan keuangan. Dari hasil uji regresi memperlihatkan koefisien ke arah positif, yang di mana jika ukuran perusahaan semakin besar, maka laporan keuangan disajikan berintegritas.

Perusahaan besar akan lebih luas menyebutkan poin-poin pada laporan keuangannya disebabkan mempunyai lebih banyak informasi untuk disajikan. Ukuran perusahaan yang besar juga di nilai mempunyai karyawan yang memiliki kemampuan dan berpengalaman dalam menyajikan laporan keuangan yang berintegritas. Selain itu besarnya perseroan juga mampu menghadapi permintaan lebih banyak lagi dari para pemegang saham guna meyajikan laporan keuangan dengan integritas. Banyaknya perhatian baik dari pasar ataupun masyarakat kepada peseroan besar dapat membuat perseroan untuk meyajikan informasi dengan jujur serta meningkatkan kesadaran manajemen betapa pentingnya informasi yang diungkapkan sehingga mencerminkan laporan keuangan dengan integritas yang baik. Penelitian yang sejalan dengan hasil uji yaitu penelitian Nurdiniah \& Pradika (2017), Saad \& Abdillah (2019) serta Verya (2017) mengungkapkan ukuran perusahaan mempengaruhi integritas laporan keuangan.

\section{KESIMPULAN}

Simpulan yang diperoleh yakni komisaris independen serta spesialisasi industri auditor mempengaruhi signifikan negatif atas integritas laporan keuangan. Kepemilikan institusional, kualitas audit serta ukuran perusahaan mempengaruhi signifikan positif atas integritas laporan keuangan. Kepemilikan manajerial tidak mempengaruhi integritas laporan keuangan. Diharapkan untuk peneliti selanjutnya bisa memperluas variabel-variabel lainnya yang diduga mempengaruhi integritas laporan keuangan diantaranya komite audit, leverage serta audit tenure, memperpanjang periode pengamatan, menambahkan model penelitian yang lain seperti model intervening ataupun model moderasi dan bisa memakai proksi pengukuran lain terkait integritas laporan keuangan seperti market to book value ratio $(M B V)$ yang dipakai oleh Beaver dan Ryan sehingga hasil penelitian yang diperoleh dapat lebih bervariasi.

Implikasinya yaitu perseroan harus mengamati tingkat komisaris independen, kepemilikan institusional, kualitas audit, spesialisasi industri auditor serta ukuran perusahaan karena sangat mempengaruhi integritas laporan keuangan. Selain itu, untuk kepemilikan manajerial sebaiknya persentase saham yang dipunya manajemen ditingkatkan karena pihak manajerial sekaligus pemegang saham akan terus berusaha untuk bekerja dengan maksimal, dan berupaya meningkatkan kinerja dan nilai perusahaan.

\section{REFERENSI}

Arista, S., Wahyudi, T. \& Yusnaini. (2018). Pengaruh Struktur Corporate Governance dan Audit Tenure Terhadap Integritas Laporan Keuangan. Akuntabilitas: Jurnal Penelitian dan Pengembangan Akuntansi, 12(2),81-98. https://doi.org/10.29259/ja.v12i2.9310

Atiningsih, S. \& Suparwati, Y. K. (2018). Pengaruh Corporate Governance dan Leverage Terhadap Integritas Laporan Keuangan (Studi Pada Perusahaan Pertambangan yang Terdaftar di BEI Periode 2012 2016)". Jurnal IImu Manajemen dan Akuntansi Terapan (JIMAT), 9(2), 110-124.

Dewi, N. K. H. S. \& Putra, I. M. P. D. (2016). Pengaruh Mekanisme Corporate Governance Pada Integritas Laporan Keuangan. E-Jurnal Akuntansi, 15(3), 2269-2296.

Fajaryani, A. (2015). Analisis Faktor-Faktor yang Mempengaruhi Integritas Laporan Keuangan (Studi Empiris pada Perusahaan Pertambangan yang Terdaftar di Bursa Efek Indonesia Periode 20082013). Jurnal Nominal, IV(1), 67-82. 
JIAFE (Jurnal Ilmiah Akuntansi Fakultas Ekonomi)
Vol. 7 No. 1, Juni 2021, Hal. 35-48

P-ISSN: 2502-3020, E-ISSN: 2502-4159

Hardiningsih, P. (2010). Pengaruh Independensi, Corporate Governance dan Kualitas Audit Terhadap Integritas Laporan Keuangan. Jurnal IImiah Kajian Akuntansi, 2(1), 61-76. https://doi.org/10.1117/12.262835

Idris, M. (2020, Januari 15). Jejak Hitam PT Hanson Internasional, Manipulasi Laporan Keuangan 2016. Kompas. https://money.kompas.com/read/2020/01/15/160600526/jejak-hitam-pt-hansoninternational-manipulasi-laporan-keuangan-2016?page=all

Indrasari, A., Yuliandhari, W. S. \& Triyanto, D. N. (2016). Pengaruh Komisaris Independen, Komite Audit, dan Financial Distress terhadap Integritas Laporan Keuangan. Jurnal Akuntansi, XX(1), 117-133. https://doi.org/10.24912/ja.v20i1.79

Irawati, L. \& Fakhruddin, I. (2016). Pengaruh Dan Kualitas Audit Corporate Governance Terhadap Integritas Laporan Keuangan. Kompartemen, 14(1), 90-106.

Istiantoro, I., Paminto, A. \& Ramadhani, H. (2017). Pengaruh Struktur Corporate Governance terhadap Integritas Laporan Keuangan Perusahaan pada Perusahaan LQ45 yang Terdaftar di BEI. Akuntabel, 14(2), 157-179. https://doi.org/10.29264/jakt.v14i2.1910

Jensen, M. C. \& Meckling, W. H. (1976). Theory of The Firm: Managerial Behavior, Agency Costs And Ownership Structure. Journal of Financial Economics, 3, 305-360. https://doi.org/10.1177/0018726718812602

Mais, R. G. \& Nuari, F. (2016). Pengaruh Good Corporate Governance, Ukuran Perusahaan, dan Leverage terhadap Integritas Laporan Keuangan. Jurnal Reviu Akuntansi dan Keuangan, 6(2), 907-912. https://doi.org/10.22219/jrak.v6i2.02

Mudasetia \& Solikhah, N. (2017). Pengaruh Independensi, Mekanisme Corporate Governance Dan Kualitas Audit Terhadap Integritas Laporan Keuangan (Studi Empiris Perusahaan Manufaktur Yang Terdaftar Di Bursa Efek Indonesia Periode 2011-2015)". Jurnal Akuntansi, 5(2), 167-178. https://doi.org/10.24964/ja.v5i2.363

Nurdiniah, D. \& Pradika, E. (2017). Effect of Good Corporate Governance, KAP Reputation, Its Size and Leverage on Integrity of Financial Statements. International Journal of Economics and Financial Issues, 7(4), 174-181.

Otoritas Jasa Keuangan. (2014). Peraturan Otoritas Jasa Keuangan Nomor 33/POJK.04/2014 tentang Direksi dan Dewan Komisaris Emiten Atau Perusahaan Publik. https://www.ojk.go.id/id/regulasi/otoritas-jasa-keuangan/peraturanojk/Documents/POJK33DireksidanDewanKomisarisEmitenAtauPerusahaanPublik_1419319443.pdf

Pratiwi, H. R. (2019, April 30). Kronologi kisruh Laporan Keuangan Garuda Indonesia. CNN Indonesia. https://www.cnnindonesia.com/ekonomi/20190430174733-92-390927/kronolog-kisruh-laporankeuangan-garuda-indonesia

Puspita, M. A. P. W. \& Utama, I. M. K. (2016). Fee Audit Sebagai Pemoderasi Pengaruh Kualitas Audit Terhadap Integritas Laporan Keuangan. E-Jurnal Akuntansi, 16(3), 1829-1856.

Qonitin, R. A. \& Yudowati, S. P. (2018). Pengaruh Mekanisme Corporate Governance dan Kualitas Audit Terhadap Integritas Laporan Keuangan pada Perusahaan Pertambangan di Bursa Efek Indonesia. ASSETS, 8(1), 167-182.

Saad, B. \& Abdillah, A. F. (2019). Analisis Pengaruh Ukuran Perusahaan, Leverage, Audit Tenure, Dan Financial Distress Terhadap Integritas Laporan Keuangan. .Jurnal Ilmu Manajemen, 15(1), 70-85.

Saksakotama, P. H. \& Cahyonowati, N. (2014). Determinan Integritas Laporan Keuangan Perusahaan Manufaktur di Indonesia. Diponegoro Journal of Accounting, 3(2), 1-13.

Savero, D. O. (2017). Pengaruh Komisaris Independen, Komite Audit, Kepemilikan Institusional dan 
Intan Nurul Octaviani: Determinasi Integritas Laporan ...

Kepemilikan Manajerial terhadap Integritas Laporan Keuangan. Jurnal Universitas Pekanbaru, 4(1), 75-89.

Sipahutar, E. V. (2017). Pengaruh Komisaris Independen, Komite Audit, Independensi, Dan Spesialisasi Industri Auditor Terhadap Integritas Laporan Keuangan. .Jurnal Online Mahasiswa Fakultas Ekonomi, 4(1), 3226-3240.

Suciani, P. \& Suprantiningrum (2018). Analisis Faktor-faktor yang Mempengaruhi Integritas Laporan Keuangan (Studi Empiris pada Perusahaan Properti dan Real Estate yang Terdaftar di BEl periode Tahun 2014-2017)". Jurnal IImiah UNTAG Semarang, 7(3), 50-72.

Sugiyono. (2016). Metode Penelitian Kuantitatif Kualitatif dan Kombinasi (Mixed Methods). Alfabet.

Sukanto, E. \& Widaryanti (2018). Analisis Pengaruh Ukuran KAP dan Tata Kelola Perusahaan terhadap Integritas Laporan Keuangan (Studi Kasus Pada Perusahaan Sektor Properti dan Real Estate yang Terdaftar di BEI Periode 2013- 2015). Jurnal Bingkai Ekonomi, 3(1), 31-42.

Syura, B. (2018). Pengaruh Mekanisme Corporate Governence Dan Spesialisasi Industri Auditor Terhadap Integritas Laporan Keuangan (Studi Empiris pada Perusahaan BUMN yang Terdaftar di Bursa Efek Indonesia pada Tahun 2013-2015). Jurnal Online Mahasiswa Fakultas Ekonomi, 4(1), 1-15.

Tussiana, A. A. \& Lastanti, H. S. (2016). Pengaruh Independensi, Kualitas Audit, Spesialisasi Industri Auditor Dan Corporate Governance Terhadap Integritas Laporan Keuangan. Media Riset Akuntansi, Auditing \& Informasi, 16(1), 69-78. https://doi.org/10.25105/mraai.v16i1.2076

Verya, E. (2017). Analisis Pengaruh Ukuran Perusahaan, Leverage dan Good Corporate Governance Terhadap Integritas Laporan Keuangan (Studi Empiris Pada Perusahaan Manufaktur yang Listing di Bursa Efek Indonesia Periode Tahun 2012-2014). Jurnal Online Mahasiswa Fakultas Ekonomi, 4(1), 982-996.

Yulinda, N. (2016). Pengaruh Komisaris Independen, Komite Audit, Leverage, Pergantian Auditor dan Spesialisasi Industri Auditor Terhadap Integritas Laporan Keuangan. Jurnal Online Mahasiswa Fakultas Ekonomi, 3(1), 419-433. 
JIAFE (Jurnal Ilmiah Akuntansi Fakultas

Vol. 7 No. 1, Juni 2021, Hal. 35-48

Ekonomi)

https://journal.unpak.ac.id/index.php/jiafe

P-ISSN: 2502-3020, E-ISSN: 2502-4159 